\title{
DIREITOS HUMANOS: POR UMA CIDADANIA AUTOGESTIONÁRIA
}

\author{
[HUMAN RIGHTS: FOR A SELF MANAGED CITIZENSHIP]
}

\author{
Antonio José Romera Valverde * \\ Pontifícia Universidade Católica de São Paulo, Brasil \\ Luiz Carlos Montans Braga** \\ Universidade Estadual de Feira de Santana, Brasil
}

RESUMO: O ensaio move-se em torno aos sinais do tempo presente, moldados, figurativamente, por densa cerração a obscurecer a visão crítica dos fins e dos meios ético-políticos da civilização tecnológica. No mesmo passo, intenciona refletir acerca dos Direitos Humanos, de modo projetivo para a invenção futura de uma cidadania de caráter autogestionário. A construção encontra-se demarcada pelo fim das ilusões, de certo modo, ainda à sombra dos cacos do ethos antigo, figurados por anacronismos, que insistem em reaparecer de modo espectral na forma de dificuldades, aparentemente, sem resolução de encaminhamento para a época atual. Para tanto, o ensaio recorre a passagens das filosofias moderna e contemporânea, de par com a poesia, o cinema e o teatro, de modo a sustentarem a defesa da teoria e da prática de uma tal cidadania. Pensada, modelarmente, desde a experiência autogestionária da Comuna de Paris, como etapa destacada de sua produção.

Palavras-chave: Direitos Humanos; crise ético-política; cidadania autogestionária; Comuna de Paris; ilusões
ABSTRACT: The essay moves around the signs of the present time, molded, figuratively, by a dense fog to obscure the critical view of the ends and the ethical-political means of technological civilization. In the same step, it intends to reflect on Human Rights, in a projective way for the future invention of a self-managed citizenship. The construction is demarcated by the end of illusions, in a way, still in the shadow of the fragments of the old ethos, figured by anachronisms, which insist on reappearing in a spectral way in the form of difficulties, apparently, with no resolution for forwarding to the current time. To this end, the essay uses passages from modern and contemporary philosophies, along with poetry, cinema and theater, in order to support the defense of the theory and practice of such citizenship. Conceived, modelly, from the selfmanaged experience of the Paris Commune, as an outstanding stage of its production.

KEYWORDS: Human Rights; ethical-political crisis; self-managed citizenship; Paris Commune; illusions

\section{"We are hollow men We are the stuffed men Leaning together Headpiece filled with straw. Alas! Our dried voices, when We whisper together Are quiet and meaningless As wind in dry grass Or rats'feet over broken glass In our dry cellar}

* Professor do Programa de Pós-Graduação em Filosofia da PUC-SP. E-mail: valverde@pucsp.br. ** Professor do Departamento de Ciências Humanas e Filosofia da Universidade Estadual de Feira de Santana-Bahia.E-mail: lcmbraga@uefs.br 
Shape without form, shade without colour, Paralysed force, gesture without motion;",

(T.S. ELIOT, The Hollow Men $)^{l}$

"Criar um animal que pode fazer promessas - não é esta a tarefa paradoxal que a natureza se impôs, com relação ao homem? Não é este o verdadeiro problema $d o$ homem?"

(NIETZSCHE, F., "Segunda Dissertação", 1, A Genealogia da Moral. Uma Polêmica, 1998)

\begin{abstract}
"Mas a emancipação humana só estará plenamente realizada quando o homem individual real tiver recuperado para si o cidadão abstrato e se tornado ente genérico na qualidade de homem individual na sua vida empírica, no seu trabalho individual, nas suas relações individuais, quando o homem tiver reconhecido e organizado suas "forces propres" [forças próprias] como forças sociais e, em consequência, não mais separar de si mesmo a força social na forma da força política."
\end{abstract}

(MARX, K., Sobre a questão judaica, 2010, p. 54)

\title{
O FIM DAS ILUSÕES
}

Q e toda leitura é fonte de contaminação e se "há mais linguagens do que se $\checkmark$ pensa", não há como ler impunemente os versos de Eliot, as palavras de Nietzsche e as de Marx sem confrontá-los com a imaginação, a justiça poética, a arquitetura e a destruição dos direitos humanos em curso, no tempo presente, sob o arco composto de desencanto e de niilismo - o fastio da concepção de homem, sobremaneira do homem moderno -, na vaga do fim das ilusões e do sumiço da norma ética universal, que haviam sustentado a civilização ocidental desde os gregos até meados da Idade Moderna. Quiçá os direitos humanos possam ser redimidos pela perspectiva de um pessimismo positivo vindouro, sob os novos parâmetros de uma cidadania autogestionária. Porém, sem o fim das classes sociais, da propriedade privada, do Estado a serviço da classe dominante, haverá alguma possibilidade de sua efetivação?

Cedendo a aspectos da imanência, quem não se lembra com tremor da personagem Coronel Kurt, vivida por Marlon Brando no filme Apocalyse Now (1979), a recitar os versos supracitados de Eliot, na descida sem volta aos infernos dos bombardeios militares de napalm durante a Guerra do Vietnã, (1955-1975), a encarnar a culpa e a má consciência dos norte-americanos, em aparente estado de desvario e de loucura, sob a lógica da contenção ideológica? Ou o aparelhamento ao padrão dessublimação repressiva, a la Marcuse? Onde estiveram os direitos humanos dos vietnamitas naqueles momentos retratados pelo cinema, e em realidade, na realidade da guerra? Onde se encontravam os direitos humanos dos jovens americanos, que a contragosto, como na peça Hair (1967), cumpriam, forçados, a invenção do patriotismo moderno, puro cálculo, sem heroísmo, sem glória e sem mácula? E para o genocídio dos Ianomâmi $(1987,1993)$ ? A escala multiplica-se em planos, que tendem ao infinito, para os dias de hoje: fome, precariedade e estranhamento do trabalho, fascismo ordinário ${ }^{2}$, terrorismo, racismo, nomadismo, advento de uma "cultura" sub-civilizatória como subproduto na linha de uma barbárie concêntrica. Porque os direitos humanos compõem parte do teto ideológico em vista de uma base material, sempre em movimento. 
Ora, os homens ocos atuais parecem mesmo não ter interioridade - como a dizer: ossos, medula, força de vida e de decisão acima do senso comum da sociedade de massas, de espetáculo e de consumo, pois, ao contrário, têm medo da vida, da morte, da doença, da perfídia, do desemprego, do neofascismo. Se comparados aos antigos, gregos do tempo da tragédia e romanos contemporâneos da República romana -, pela força de dizer sim à vida e de criar valores elevados, universais, por não temerem a vida nem a morte, as doenças nem as perfídias, desvelava-se a pujante interioridade de homens fortes e sem medo. Ao menos para a imaginação projetada por aqueles homens a viajar na noite escura da História. Assim, os versos de Eliot retratam a fraqueza dos valores do homem contemporâneo, o esgotamento do sentido, o vazio ético, a ausência de horizontes de negação da avassaladora ordem econômico-social em curso. Quem tem pago para contradizer, radicalmente, a ordem em curso? Contudo, talvez desse cenário de ruínas possa advir, aos moldes de um desdobramento dialético, o valor novo para além do atual tempo murcho, em vista de um futuro livre de ilusões. - Se houver tempo e existência humana para tanto.

Se a Filosofia principia com admiração do espetáculo do mundo, os direitos humanos, postos à prova desde a Primeira Guerra Mundial até o presente, por hipótese, talvez possam, - em movimento contínuo de negação dialética -, mover o pensamento crítico e a práxis política para além de sua decepção. George Steiner aponta que, entre 1820 e 1915, a Europa teria vivido sob o mito do "jardim imaginado da cultura liberal", a circunscrever uma prolongada estação de verão. Logo, de 1915 até os dias atuais vivese um outono sem fim de destruição das aquisições das alturas civilizatórias (STEINER, 1991, p. 15). Porém, a investida de Steiner não corresponde aos fatos históricos, sobremaneira, se relembrados as insurgências políticas de 1830, 1848 e 1871, que sacudirem a Europa, dentre outros acontecimentos, sob a consolidação do colonialismo em África. Contudo, a metáfora recorrente do verão mais revela que esconde a descoberta das forças humanas até então ocultas, que se revelaram na forma trabalho, segundo Marx. Todavia, como a contradição tudo conduz, a eclosão da Primeira Guerra Mundial deve ser a alegoria projetada do tenaz verão ideológico. Aquisições humanas reais, subsidiadas e compostas de ilusões fracas, sem substrato de nexos causais com a realidade mais profunda do mundo real, em movimento, não resistiram à prova de fogo - escorpião encravado na própria ferida. Em verdade, vive-se um longo outono. Por fim, para trazer o tema à geografia pátria, com fina ironia e senso de justiça poética, Carlos Drummond de Andrade secunda: "(No Brasil não há outono, mas as folhas caem)" (DRUMMOND, 1979, p. 93).

\section{IMAGINAÇão, InVENÇão, DESTRUIÇão}

Em um rasgo de expressão do prometeísmo redivivo e de endeusamento do homem, em curso desde o final da Idade Média e a adentrar os tempos modernos, Pico della Mirandola escreveu, em $1486^{3}$, um manifesto na forma combinatória de elogio altivo e de apologia do homem, no opúsculo Oratio de Hominis Dignitate. À sombra de autores antigos e medievais, pelo procedimento heterodoxo-eclético, sob cunho retórico evidente, Pico concebia o homem pelo livre-arbítrio e pela possibilidade de transformar-se no que desejasse ser. A propósito registrou:

Ó suprema liberalidade de Deus Pai, ó suprema e maravilhosa beatitude do homem! A ele foi dado possuir o que escolhesse; ser o que quisesse. Os animais, desde o nascer, já trazem em si (como quer Lucílio) ${ }^{4}$, 'no ventre materno', o que irão possuir depois. Os espíritos superiores, a partir do início ou logo depois, já 
eram aquilo que pela eternidade seriam. No homem, todavia, quando este estava por desabrochar, o Pai infundiu todo tipo de sementes, de tal sorte que tivesse toda e qualquer variedade de vida... [E conclui] Quem não admiraria esse novo camaleão? Ou que outra coisa mais digna de ser admirada? (PICO della MIRANDOLA, 1999, pp. 54-55).

Ecos dos aportes à dignidade humana, em vista das reviravoltas da Idade Moderna, forjados por Pico della Mirandola encontram-se, grosso modo, em Giordano Bruno, Pascal e Rousseau, para quem a diferença do homem em relação aos outros animais advém do fato de ser o animal humano menos forte, porém mais organizado. Como expressão da revanche do homem comum frente à excessiva exaltação piquiana da dignidade do homem, François Rabelais, monge beneditino, humanista e médico, décadas após esboçou apenas, mas não redigiu, um ensaio com o engenhoso título de Da Dignidade das Braguilhas. Pela linhagem do humor escatológico, em Gargantua e em Pantagruel, Rabelais registrara a revanche do homem renascentista contra a natureza sacralizada, dos medievais, em descenso, em vista da concepção de homem como ser natural.

Antecipando a tensão ético-política acerca dos direitos humanos da contemporaneidade, antes mesmo de seu surgimento do movimento político em prol das declarações dos direitos humanos no século XVIII, Samuel Pufendorf escrevera Os Deveres do Homem e do Cidadão de acordo com as Leis do Direito Natural, publicado em sueco em 1673, traduzido para o inglês em 1691. Batendo-se pelo princípio do desejo de autopreservação, ao qual sucumbem todos os apetites e as paixões, fundado no direito natural, Pufendorf assegurava que a igualdade natural dos homens deve ser reconhecida como condição de cumprimento da dignidade humana, porquanto ser o modo de tornar os homens benevolentes, corteses e complacentes uns com os outros, além de forçar a observação comum da justiça distributiva ao dar a cada um o que lhe é próprio, e ainda ser remédio eficaz contra o orgulho. Para Pufendorf: "O Homem é uma Criatura não só extremamente solícita quanto à Preservação de Si Mesmo, como também tem por Si Mesmo Valor e Estima tão altos que diminuí-lo nisso em alguma coisa frequentemente o leva a uma tal Indignação como se um Dano houvesse sido feito a seu Corpo ou Propriedade."

Ao que acrescentou:

[...] parece haver para ele algo de Dignidade nesse Chamamento de Homem: de forma que o último e mais eficaz Argumento para sujeitar a Arrogância de Homens Insultuosos é geralmente: Eu não sou um Cachorro, mas um Homem, tal como você. Uma vez que a Natureza Humana é a mesma em todos nós, e uma vez que Homem nenhum irá ou poderá unir-se em Sociedade com alguém por quem não seja pelo menos estimado como igualmente Homem e Partícipe da mesma Natureza Comum: Segue-se que, dentre os Deveres que os Homens têm um para com o outro, este ocupa o segundo Lugar, o de Que todo Homem estime e trate um outro como naturalmente igual a si mesmo, ou como alguém que é um Homem tal como ele (PUFENDORF, 2007, p. 157). ${ }^{5}$

Arrematando:

ora, essa Igualdade da Espécie Humana não apenas consiste nisso, que Homens de Idade madura têm quase a mesma Força ou, se um for mais fraco, talvez possa matar o mais forte, ou por Malicia traiçoeira, ou por Engenho e Perícia, ou por estar mais bem munido de Armas, mas consiste também em que, embora a Natureza possa ter aperfeiçoado um Homem mais do que um outro com vários Dotes de Corpo e Mente, apesar disto, ele é ainda obrigado a uma Observação dos Preceitos do Direito Natural para com a pessoa mais fraca, da mesma maneira 
como ele próprio espera a mesma coisa dos outros; e, portanto, não recebeu nenhuma maior Liberdade de insultar seus Semelhantes (Idem, pp. 157-158).

Tal concepção de direito natural, que traz em sua estrutura a natureza comum do humano como fundamento, por certo, ainda em eco à tese de Pico della Mirandola acerca da dignidade do homem, foi alvo de contestações ao longo da história das ideias. Assim, o direito natural e suas derivações receberam críticas pontuais desde os primórdios, tanto em campo próprio do Direito e da Filosofia. Em movimento de decomposição da suposta pantomima do direito natural, Walter Benjamin, ao tratar da crítica da violência e do poder, de modo aparentemente esquemático, registrou:

O direito natural não vê problema nenhum no uso dos meios violentos para fins justos; esse uso é tão natural como o 'direito' do ser humano de locomover seu corpo até determinado ponto desejado. Segundo essa concepção (que serviu de base ideológica ao terrorismo na Revolução Francesa), a violência é um produto da natureza, por assim dizer, uma matéria-prima utilizada sem problemas, a não ser que haja abuso da violência para fins injustos. Se, de acordo com a teoria política do direito natural, todas as pessoas abrem mão de seu poder em prol do Estado, isso se faz, porque se pressupõe (como mostra explicitamente Spinoza no Tratado Teológico-Político) que, no fundo, o indivíduo - antes de firmar esse contrato ditado pela razão - exerce também de jure qualquer tipo de poder que, na realidade, exerce de fato.[...] À tese, defendida pelo direito natural, do poder como dado da natureza, se opõe diametralmente a concepção do direito positivo, que considera o poder como algo que se criou historicamente. Se o direito natural pode avaliar qualquer direito existente apenas pela crítica de seus fins, o direito positivo pode avaliar qualquer direito que surja apenas pela crítica de seus meios. Se a justiça é o critério dos fins, a legitimidade é o critério dos meios. No entanto, não obstante essa contradição, ambas as escolas estão de acordo num dogma básico comum: fins justos podem ser obtidos por meios justos, meios justos poder ser empregados para fins justos. O direito natural visa, pela justiça dos fins, 'legitimar' os meios, o direito positivo visa 'garantir' a justiça dos fins pela legitimidade dos meios. A antinomia se revelaria insolúvel, se o pressuposto dogmático comum fosse falso, se meios legítimos de um lado e fins justos de outro lado estivessem numa contradição inconciliável. Sua compreensão não seria possível sem sair do círculo, estabelecendo critérios independentes para fins justos e para fins legítimos (BENJAMIN, 1986, pp. 160-161). ${ }^{6}$

Como assinala o tradutor do ensaio, Willi Bolle, Benjamin parece ter tangenciado o cerne do problema da violência e do direito ao usar a expressão Gewalt. Com efeito, o título do ensaio, na língua original, é Zur Kritik der Gewalt. Optando por Crítica da Violência - Crítica do Poder. E, de fato, não poderia ser outra a tradução sem perda do essencial do ensaio benjaminiano, pois a expressão Gewalt significa simultaneamente violência e poder. Há uma ambiguidade constitutiva da expressão. A intenção de Benjamin é, pois, segundo Bolle, e como se depreende do ensaio, mostrar a origem do direito - e do poder judiciário - a partir do espírito da violência. ${ }^{7}$ Em uma palavra, poder e direito não se sabem diversos, não se manifestam um sem o outro. Essa uma lição de Benjamin no ensaio. Alerta máximo às ilusões, que se expressam de modo vário, cuja essência seria a de tratar o direito como o avesso da violência, ou mesmo como solução em face da violência.

Recorrendo à História. Marx, ao tratar da "chamada acumulação primitiva" e ao desenvolver a análise do pauperismo inglês e da violência na destruição da pequena propriedade agrícola, das leis contra os trabalhadores, aponta para uma contradição da efetivação da Revolução Francesa. Afirma Marx: 
Já no início da tormenta revolucionária, a burguesia francesa ousou despojar novamente os trabalhadores de seu recém-conquistado direito de associação. $\mathrm{O}$ decreto de 14 de julho de 1791 declarou toda coalização de trabalhadores como um 'atentado à liberdade e à Declaração dos Direitos Humanos', punível com uma multa de 500 libras e privação, por um ano, dos direitos de cidadania ativa. Essa lei, que por meio da polícia estatal impõe à luta concorrencial entre capital e trabalho obstáculos convenientes ao capital, sobreviveu a revoluções e mudanças dinásticas. Mesmo o regime do Terror a manteve intocada. Apenas muito recentemente ela foi riscada do Code Penal [código penal]. Nada mais característico que o pretexto desse golpe de Estado burguês (MARX, 2013, pp. 812-813).

Ao que prossegue, registrando:

“Ainda que seja desejável' - diz Le Chapelier - 'que o salário ultrapasse seu nível atual, para que, desse modo, aquele que o receba escape dessa dependência absoluta condicionada pela privação dos meios de primeira necessidade, que é quase a dependência da escravidão', os trabalhadores não devem ser autorizados, contudo, a pôr-se de acordo sobre seus interesses, a agir em comum e, por meio disso, a mitigar sua 'dependencia absoluta, que é quase a dependência da escravidão', porque assim feririam a 'liberdade de seus ci-devant maitres [antigos mestres], dos atuais empresários'(a liberdade de manter os trabalhadores na escravidão!), e porque uma coalização contra o despotismo dos antigos mestres das corporações - adivinhe - equivaleria a restaurar as corporações abolidas pela constituição francesa! (MARX, 2013, p. 813).

A mostrar que a classe burguesa por vezes tropeça sobre si mesma...

Direito natural ou direito nacional? Bobbio, noutra chave de análise, em A Era dos Direitos, afirma que os direitos naturais são históricos e nasceram ao início da Idade Moderna, de par com a concepção individualista de sociedade e tornaram-se os indicadores principais do progresso histórico. Sustenta igualmente que os "Direitos do homem, democracia e paz são três momentos necessários do mesmo movimento histórico: sem direitos do homem reconhecidos e protegidos, não há democracia; sem democracia, não existem as condições mínimas para a solução pacífica dos conflitos." (BOBBIO, 2004, p. 21).

Consideradas, cronologicamente, as declarações dos direitos humanos tiveram seus primeiros registros na Declaração do Bom Povo da Virginia, de 16 de junho de 1776, seguida da Declaração de Independência dos Estados Unidos, de 04 de julho de 1776, e por fim em a Declaração de Direitos do Homem e do Cidadão, de 26 de agosto de 1789 - da Revolução Francesa. De acordo com Fábio Konder Comparato, verificase, no correr da história da humanidade, uma afirmação histórica crescente dos direitos humanos. Assim, uma das primeiras manifestações dos direitos do homem, em verdade, o que se poderia chamar de uma proto-manifestação de limites ao poder do monarca do governante - estaria na Magna Carta, de 1215, de Inglaterra. Pois, se configuraria naquele documento a afirmação de direitos individuais subjetivos em face de um protoEstado. No documento, entre outros pontos, limites ao poder do rei João Sem-Terra foram impostos por barões feudais. Nas palavras de Comparato,

a Magna Carta constitui, na verdade, uma convenção passada entre o monarca e os barões feudais, pela qual se lhes reconheciam certos foros, isto é, privilégios especiais [...]. O sentido inovador do documento consistiu, justamente, no fato de a declaração régia reconhecer que os direitos próprios dos dois estamentos - a nobreza e o clero - existiam independentemente do consentimento do monarca, e 
não podiam, por conseguinte, ser modificados por ele. Aí está a pedra angular para a construção da democracia moderna: o poder dos governantes passa a ser limitado, não apenas por normas superiores, fundadas no costume ou na religião, mas também por direitos subjetivos dos governados.

Por exemplo, para majorar tributos, os barões deveriam ser consultados. O que está em germe é a necessidade de consulta e de consentimento dos representados, via representantes, para que haja criação ou majoração de tributos (cláusulas 2 e 14) (COMPARATO, 2001, pp. 75-77). ${ }^{8}$

Marx e Benjamin, alinhados em bloco crítico, ou Fábio Comparato e a tese da afirmação histórica, as quais sob chaves de análises convergentes, em certa medida, ainda parecem ecoar os escritos de Pico della Mirandola acerca da dignidade humana. Porém, qual tem sido o peso efetivo dos direitos humanos na História? Acaso, bastam declarações? Mantêm apenas o valor simbólico diante dos fatos crus da existência de milhares de homens concretos, que têm seus direitos humanos desrespeitados diária e frequentemente? Ou têm o peso das ideias em via de concreção para mudar a materialidade das práticas históricas? A História tem mostrado o peso da materialidade da competição crua, dos Estados violadores de direitos básicos, dos homens ocos em face das declarações tornadas letra morta, e não. Entretanto, a História é campo aberto e o homem ser histórico e, por essa razão, poroso aos possíveis utópicos. Possíveis utópicos não como horizontes inalcançáveis, mas como ideais, que findam por moldar o real e o formatam, como pensa Ernst Bloch desde a noção de "ainda-não consciente" em vista da construção ontológica da utopia concreta, ao tempo presente, histórico. $\mathrm{O}$ futuro encontra-se aberto à plasticidade constitutiva do humano. Porém, em se tratando do horizonte próximo, os entraves à realização dos direitos humanos têm mostrado suas garras afiadas.

\section{Prova de Fogo}

Ao tempo em que a aplicação de torturas físicas e morais com o fim de obter confissões parecia abandonada, ressurgiu com força no começo do século em curso. Entre os prisioneiros de guerra do Iraque, custodiados por soldados norte-americanos, entre os cidadãos considerados terroristas, ao menos como possibilidade, em Inglaterra, pois na pérfida Albion "fala-se" em tortura justificada como meio de zelar pelo bem público. Deve-se rememorar as torturas realizadas em delegacias e em prisões pátrias sem motivos políticos aparentes e as executadas nos calabouços da ditadura civil militar brasileira dos anos de chumbo do século passado. Naqueles tempos, Tiago de Melo reescreveu os direitos humanos, sob um lirismo sem grande tensão poética e de horizonte utópico aparentemente anêmico. Limites de uma consciência possível no tempo. O poema intitula-se Os Estatutos do Homem. ${ }^{9}$ Frente ao inominável da prática da tortura em nossos dias, o recurso à justiça poética redime sem minorar a situação, como explícito em poema de Roberto Schwarz:

Escovou os dentes até que sangrassem. Parou de escovar quando começaram a sangrar. Não escove até que sangrem. Meus dentes sangram tão logo comece a escová-los. Antes, precisava escovar muito, agora é começar e já estão sangrando. Basta aproximar a escova e começam a sangrar. Às vezes penso numa escova mais mole, mas sei que mesmo um pincel de barba esfregando bastante, não faz menos efeito que o arame. (SCHWARZ, 1974). 


\section{Afinando o CORO DOS DESCONTENTES}

Cidadania universal. Quando perguntaram a Sócrates de onde ele era, respondeu: "sou cidadão do universo". Não respondeu: de Atenas. Tempos após, o filósofo cínico Diógenes proclamava-se "cidadão do mundo". Contra o pastiche da cultura aldeã francesa de meados do século XVI, ao tempo das guerras religiosas, Montaigne registrou: "Da frequentação da sociedade tira-se maravilhosa clarividência para julgar os homens. Vivemos todos apertados, dentro de nós mesmos, e não vemos um palmo diante do nariz. Perguntaram a Sócrates de onde era e ele não respondeu: de Atenas, mas: do mundo. Para ele, cuja inteligência mais vasta e aberta que de outrem abarcava o universo e dele fazia sua cidade, o objeto de sua afeição era o gênero humano; e não agia como nós que apenas olhamos em torno de nós" (MONTAIGNE, L. I, XXVI, 1984, p. 80).

A globalização como padronização não só econômica, mas de comportamento e de pensamento único, parte da vitória do positivismo com a filosofia negativa, trouxe no seu bojo o multiculturalismo - em síntese, a possibilidade da cidade universal, com todos os riscos de uma civilização universalizante a corromper e a destruir as singularidades culturais, regionais. No pós Império universal - inventado por Dante e redimido por Negri e Hardt - a cidadania universal bem poderá ser lastreada como condição para a maioridade humana. Como forma de saída da menoridade das convenções e das restrições nacionais e territoriais, em que a lei, para ter validade universal, estivesse submetida ao reconhecimento universal, desde as diferenças basilares entre todos os homens. Desde a explicitação das contradições naturais e sociais, para a invenção de lei de caráter universal, que dê conta de assegurar, do modo dialético, a igualdade dos homens como cidadãos do planeta Terra.

Contudo, o fato do Estado brasileiro ser signatário da Declaração Universal dos Direitos Humanos, proclamada em 1948, favoreceu a luta política contra a ditadura civil-militar nos anos 70 do século passado, dada a necessidade de observância de parte significativa de seus artigos pelos usurpadores da democracia, de plantão. Eis o peso simbólico das declarações operando na materialidade da História.

Lembrando que a Declaração dos Direitos Humanos, de 1948, foi pautada pelo pensamento neotomista de Jacques Maritain, sobremaneira de seu livrinho Cristianismo e Democracia (MARITAIN, 1964), em que esclarece o que venha a ser direitos naturais, de par com a derrocada das democracias e o que pode ser caracterizado como um certo humanismo heroico. Em verdade, o presidente Roosevelt indicara Maritain, praticamente seu representante teórico, para compor o quadro de redatores da Declaração dos Direitos Humanos, cujo título original era Direitos do Homem. Porque, naquele momento, ao que tudo indica somente Maritain possuía uma síntese filosófica sólida para tal fim. - $\mathrm{O}$ universo de valores cristãos dera as cartas.

Porém, como pode o homem cumprir promessas, segundo Nietzsche, um dos mais perfeitos destruidores de máscaras sociais? Camões alertara:

Na terra, tanta guerra, tanto engano,

Tanta necessidade avorrecida!

Onde pode acolher-se um fraco humano,

Onde terá segura a curta vida,

Que não se arme e se indigne o Céu sereno,

Contra um bicho da terra tão pequeno? (CAMÕES, 1974, p. 79). 


\section{Cidadania universal autogestionária}

Dado o quadro contemporâneo de homens ocos, de tempos murchos e sem virtù, quiçá trazer à luz a lucidez de Marx, de modo a aditar força à proposição de uma cidadania universal e autogestionária, como se verá adiante. Neste passo, algumas ideias incipientes, sem qualquer pretensão de esgotar o assunto, sob a capa de conceitos trazidos ao debate como pequenas peças para a construção de novas figuras conceituais, de novos mosaicos explicativos. Acerca da cidadania autogestionária, dois momentos de análise: primeiro, alguns argumentos extraídos do ensaio de Marx, Sobre a questão judaica (MARX, 2016), movimentados com a intenção de mostrar sua contribuição ao debate dos direitos humanos, ao alargar o conceito de emancipação para além da retórica iluminista; após, a análise de Marx da Comuna de Paris, objeto de apontamentos.

O ensaio intitulado Sobre a questão judaica é, em parte, uma resposta de Marx aos argumentos de Bruno Bauer acerca da situação dos judeus na Prússia. Porque Marx toma como principais referências, em seu texto, dois escritos de Bauer sobre a questão dos direitos dos judeus naquele Estado. ${ }^{10} \mathrm{O}$ ponto que talvez se destaque da argumentação marxiana, o qual será desdobrado a seguir, é o da necessidade de que o conceito de emancipação seja mais amplo que o de direitos humanos, o qual vem carregado da influência histórica das posições burguesas. Do contrário, isto é, sem que se leve em conta o conceito de emancipação real do homem, o conceito de direitos humanos perde seu sentido forte, coletivo. É preciso considerar uma definição de emancipação alargada, que se encaminhe além da garantia do egoísmo, da mera defesa da liberdade de comércio, da segurança e da propriedade. Se assim for, tem-se apenas a garantia do projeto burguês, não a da emancipação (MARX, 2016, p. 53).

Marx inicia o ensaio com uma indagação, da qual seu texto será um aprofundamento pontual: "Os judeus alemães almejam a emancipação. Que emancipação almejam? A emancipação cidadã, a emancipação política" (MARX, 2016, p. 33).

Porém, segundo Marx, o erro de Bauer na análise da questão é, exatamente, sua limitação. Com efeito, indaga Marx: "É nesse ponto que se evidencia a compreensão unilateral da questão judaica. De modo algum bastava analisar as questões: quem deve emancipar? Quem deve ser emancipado? A crítica [...] devia perguntar: de que tipo de emancipação se trata? Quais são as condições que têm sua base na essência da emancipação exigida?" (MARX, 2016, p. 36). E conclui: "Bauer incorre em contradições por não alçar a questão a esse nível” (MARX, 2016, p. 36).

Marx proporá uma resposta que se distancia da questão teológica, respondendo a questão da emancipação frente ao Estado, o qual não é um Estado qualquer, mas aquele cujos direitos garantidos passam antes pela garantia do egoísmo burguês, que pela garantia da emancipação, tal qual Marx a definirá - um conceito bem mais exigente que as garantias dos egoísmos. Com efeito, Marx indica que não se pode transformar a questão mundana em teológica; deve-se, isto sim, transformar as questões teológicas em mundanas (MARX, 2016, p. 38). Arremata com a seguinte tese: "A questão da relação entre emancipação política e religião transforma-se para nós na questão da relação entre emancipação política e emancipação humana" (MARX, 2016, p. 38). Pois, não basta, como propunha Bauer, ao judeu - ou a qualquer praticante de uma religião -, "que renuncie ao judaísmo, que o homem em geral renuncie à religião, para tornar-se emancipado como cidadão" (MARX, 2016, p. 36).

A questão que se põe, a contradição que se apresenta, é a de que pode existir um Estado livre (uma república) sem que o homem seja um homem livre (MARX, 2016, p. 
39). Eis o ponto que Marx lança à luz, que se apresenta como a contradição a ser superada. Vez que a "emancipação política de fato representa um grande progresso; [mas] não chega a ser a forma definitiva da emancipação humana em geral [...]" (MARX, 2016, p. 41).

Qual o limite? Qual a contradição? Onde está o ponto central da crítica marxiana? Após analisar os termos positivados nas constituições das sociedades burguesas, como, por exemplo, a Constituição de 1793 (França), aos chamados direitos do homem, constata que "nada mais são dos que os direitos do membro da sociedade burguesa, isto é, do homem egoísta, do homem separado do homem e da comunidade" (MARX, 2016, p. 48). Veja-se que o artigo 2 da Declaração dos Direitos do Homem e do Cidadão, de 1793, que Marx cita e analisa, afirma literalmente que "Estes direitos etc. [os direitos naturais e imprescritíveis] são a igualdade, a liberdade, a segurança e a propriedade" (MARX, 2016, p. 48). E conclui, ironicamente, mostrando que os homens, na conjuntura histórica em análise, equivalem a coisas, tese que terá desdobramentos em $O$ Capital, na análise do fetiche da mercadoria e da mercantilização da vida em todos os aspectos: "O limite dentro do qual cada um pode mover-se de modo a não prejudicar o outro é determinado pela lei do mesmo modo que o limite entre dois terrenos é determinado pelo poste da cerca" (MARX, 2016, p. 49).

A "liberdade do homem como mônada isolada recolhida dentro de si mesma" (MARX, 2016, p. 49) não corresponde a uma liberdade que conduza à emancipação do homem. A inversão, sob a sutil análise marxiana, da sociedade burguesa é a seguinte: a vida política, pela via do Estado, é simples meio, cujo fim real é a vida da sociedade burguesa. De fato, os direitos humanos à liberdade de imprensa, à segurança, entre outros, seriam apenas teóricos, asseguradores de outros fins. Conforme Marx:

No mesmo momento em que [...] a segurança é declarada como um direito humano, põe-se a violação do sigilo à correspondência publicamente na ordem do dia. No mesmo momento em que a 'liberté indéfinie de la presse' [...] é garantida como consequência do direito humano à liberdade individual, a liberdade de imprensa é totalmente anulada [...]" (MARX, 2016, p. 51).

Neste último caso, toda vez que a liberdade de imprensa fere a liberdade universal [liberté publique] - segundo a interpretação de que instância do Estado? -, deve ser anulada (MARX, 2016, p. 51). Conclui Marx, sobre estes direitos apenas teóricos, que "a práxis é apenas exceção, a teoria é a regra” (MARX, 2016, p. 51).

Dado o estado de coisas desta organização social, com este Estado, a solução proposta por Marx ao enigma das coisas postas de cabeça para baixo é definir a emancipação política como representando "a dissolução da sociedade antiga, sobre a qual está baseado o sistema estatal alienado do povo, o poder do soberano" (MARX, 2016, p. 51). De fato, a burguesia destruiu o sistema feudal. Esta foi sua revolução. Porém, traços dos elementos constitutivos da vida burguesa foram introjetados como elementos da vida estatal. Desse modo, "a unidade do Estado, assim como o poder universal do Estado, que constitui a consciência, a vontade e a atividade da unidade do Estado, manifestam-se como assunto particular de um soberano e de seus serviçais, separados do povo" (MARX, 2016, p. 52).

O homem egoísta é o que prevalece, pois, a emancipação política trouxe como corolário a emancipação da sociedade burguesa em face da política (MARX, 2016, p. 52). O homem egoísta, membro da sociedade burguesa, passa a ser, segundo Marx, a base do Estado político. O Estado político fundado pela burguesia reconhece tal homem egoísta nos direitos humanos. Corolário deste estado de coisas material e espiritual: "o homem não foi libertado da religião. Ele ganhou a liberdade de religião. Ele não foi 
libertado da propriedade. Ele ganhou a liberdade de propriedade. Ele não foi libertado do egoísmo do comércio. Ele ganhou a liberdade de comércio" (MARX, 2016, p. 53).

Portanto, a inversão a que se refere Marx é aquela em que meios de real emancipação nunca aparecem. O que se apresenta é um conjunto de normas postas que garantem em teoria o que nunca se realiza ao homem de fato. E todo o aparato estatal garante de fato os fins da sociedade burguesa: comércio, segurança para as transações privadas, propriedade e liberdade de expressão, desde que esta última não faça desmoronar os valores próprios à burguesia. A emancipação real, do homem concreto, nunca ocorre. Portanto, a emancipação, tal como conceituada por Marx, não poder vir dos direitos humanos definidos pela pena burguesa e pela práxis desta classe.

A emancipação política, nos moldes acima definidos, apenas é a emancipação do cidadão como pessoa moral e do membro da sociedade burguesa definido como "indivíduo egoísta independente" (MARX, 2016, p. 54). Escreve Marx, nesse sentido, que:

a emancipação humana só estará plenamente realizada quando o homem individual real tiver recuperado para si o cidadão abstrato e se tornado ente genérico na qualidade de homem individual na sua vida empírica, no seu trabalho individual, nas suas relações individuais, quando o homem tiver reconhecido e organizado suas "forces propres" [forças próprias] como forças sociais e, em consequência, não mais separar de si mesmo a força social na forma da força política (MARX, 2016, p. 54).

Desse modo, Marx é capaz de explicitar o ponto-chave das ilusões jurídicas estatais em forma de direitos humanos do homem egoísta burguês. A inversão é posta à luz e o conceito de emancipação deixa de ser o fantasma nunca alcançável para ganhar materialidade, práxis. A força social, isto é, a dos homens individuais reais em luta com os iguais na condição de expropriados de si mesmos, de sua humanidade, é o motor da emancipação a ser alcançada. A emancipação é fillha da práxis libertária de uma classe.

Talvez as revoluções marxistas ${ }^{11}$, feitas com apropriação indevida das teses de Marx, sejam apenas fantasma, ilusão, delírio, em relação a um evento tão rápido quanto denso de significado emancipatório, a saber, a Comuna de Paris. Passa-se, a seguir, ao desenvolvimento de algumas notas acerca deste importante e potente evento, com vistas a levantar argumentos a favor da autogestão.

A Comuna de Paris, primeiro governo civil de base popular, principalmente, proletária, auto organizada e autogestionária, gestada desde a Revolução Francesa de 1789, logo, sob fermentação por oitenta e dois anos, durou setenta e dois dias. Porém, precedidos de oitenta e um anos de preparação, pois os ideais da Revolução Francesa haviam sido traídos, desde a transformação da República em Império, e a Restauração de 1830. Havia uma fermentação e radicalização dos ideais da Revolução de 1789, que desaguaram na Comuna de Paris. A Comuna institui um governo republicano, de fato e de direito, destituindo o Estado de seus poderes, as Câmaras Legislativas e o Judiciário, autoritários e corruptos, que constituíram as "falsas" repúblicas monárquico-burguesas da França, como o Império napoleônico na contramão dos ideais da Grande Revolução, a Revolução de 1789 .

O governo da Comuna instituiu Comitês de bairros de Paris, que elegiam seus representantes encarregados de apresentar e defender as reivindicações do bairro ao Conselho Central. Após, devia retornar ao bairro para prestar contas de trabalho à população, que o elegera. Assim, eram delegados, vigiados e podendo ser destituídos a qualquer momento, diferentemente dos modos da democracia liberal, em que os representantes têm mandato e imunidades intocáveis, como parte do foro privilegiado, 
que os protege. Lançados candidatos somente pela cúpula dos partidos, em geral, distantes do povo e dos bairros.

Assim, as reformas políticas, aos moldes de uma antipolítica revolucionária instituídas pela Comuna, foram: separação Igreja e Estado; educação gratuita, secular e compulsória; criação de escolas, para meninas e meninos; duplicação do salário do professor, fixado em dois mil francos anuais; salário para artistas e cientistas, de modo a sobreviverem; fixação do ordenado máximo de seis mil francos anuais e proibição de acumulação de empregos; pagamento dos membros da direção da Comuna de quinze francos diários; abolição dos descontos dos salários; redução da jornada de trabalho com proposta de oito horas diárias; abolição do serviço militar e do exército regular; abolição da pena de morte; fim do monopólio da Lei pelos advogados; fim dos honorários advocatícios; gratuidade de testamentos, adoções, contratação de advogados, casamento; proibição de investigação sem mandado judicial pela Comuna; concessão de pensão às viúvas e aos órfãos; proibição da circulação de veículos no centro de Paris, exceto bicicletas; derretimento de imagens de santos; antigos ministérios substituídos por comissões eletivas. A Comuna de Paris é, historicamente, o primeiro modelo de cidadania autogestionária (LISSAGARAY, 1991, pp. 116-119).

Contudo, pelo ineditismo, a experiência histórica tem fortuna crítica submersa em polêmica. Como poderia ser exemplo evento tão fugaz, mas, fortíssimo do ponto de vista da ação política? ${ }^{12}$ Teria algo a ensinar? Uma hipótese é a de que a memória do evento sofreu tentativas de apagamento. Será necessário um processo de pentimento para retirar a pátina acumulada sobre sua pintura original. $\mathrm{O}$ argumento, geralmente aceito, acerca das razões do apagamento, pode ser resumido na indagação seguinte: como poderia o povo tomar o poder e criar institucionalidades novas e tendentes à horizontalidade? Pois os desentendimentos entre os membros certamente levariam, em pouco tempo, o projeto à ruína. Afinal, quem funda sobre a multidão funda em solo frágil, tese da qual Maquiavel se distanciará em $O$ Príncipe ao escrever que "não venha ninguém retorquir a esta minha opinião [de que o príncipe deve ter o povo ao seu lado, sob pena de flertar com o fracasso] com aquele provérbio desgastado: "quem funda sobre povo funda sobre lodo"' (MAQUIAVEL, 2017, p. 151). ${ }^{13} \mathrm{Na}$ sequência do texto maquiaveliano, defende-se a tese de que o governo com apoio do povo terá boas fundações (MAQUIAVEL, 2017, p. 151).

A aurora de 18 de março de 1871, em Paris, se dá com o grito "Viva a Comuna!" (MARX, 2016, p. 54). Que é esta esfinge que tanto atormenta os espíritos burgueses, indaga Marx? (MARX, 2016, p. 54). Trata-se do momento em que os proletários de Paris resolvem tomar em suas mãos os negócios públicos da cidade. Não se trata, entretanto, de apenas tomar a máquina do Estado e dela se servir. Pois o Estado é polícia, magistratura, burocracia, clero (MARX, 2016, p. 54) - e estas instituições devem ser extintas, e o foram, pela Comuna. O poder estatal centralizado é, grosso modo, o final de uma cadeia de eventos, que se inicia com o encerramento do modo feudal de produção, pelas ações revolucionárias da burguesia, passa por várias etapas, e na França chega como república parlamentar, cujo último ato foi o golpe de Luís Bonaparte (02 de dezembro de 1851), certidão de nascimento do Império. ${ }^{14}$ Afirma Marx: "o fruto natural da República do "Partido da Ordem" foi o Segundo Império"(MARX, 2016, p. 55). A Comuna, por sua vez, é definida por Marx como a antítese do império, ou seja, o oposto do cume ao qual as ações da burguesia levaram. A Comuna veio a ser a forma positiva do desejo de república do proletariado, o qual não foi antes atendido, senão falsamente. Pois a Comuna aboliu o exército e era composta por conselheiros municipais eleitos por sufrágio universal nos diversos distritos da cidade. A maioria de seus membros era formada de operários ou representantes desta 
classe. Não era um órgão parlamentar, mas uma corporação de trabalho, que executava e legislava ao mesmo tempo. Entre as reformas realizadas, está a submissão da polícia e da burocracia estatal à Comuna (MARX, 2016, p. 57). E, um dos fundamentos da política implementada, "Dos membros da Comuna até os postos inferiores, o serviço público tinha de ser remunerado com salários de operários." Para quebrar a força espiritual da opressão, segundo Marx, a Comuna desoficializou e expropriou todas as igrejas como corporações proprietárias. Por seu turno, todas as instituições de ensino foram abertas ao povo gratuitamente. A influência do Estado e da igreja foram retiradas (MARX, 2016, p. 57). Os funcionários da justiça e demais servidores públicos passaram a ser eleitos, responsáveis e demissíveis (MARX, 2016, p. 57). Havia, segundo Marx, um projeto de nacionalização do modelo da Comuna, o qual deveria operar em todas as instâncias do território. Ela deveria ser "a forma política até mesmo das menores aldeias do país” (MARX, 2016, p. 57). O espírito desta construção institucional política, cujo poder intentava ser bastante espraiado, pode bem ser resumido na seguinte passagem: "nada podia ser mais estranho ao espírito da Comuna do que substituir o sufrágio universal por uma investidura hierárquica" (MARX, 2016, p. 58). Tratava-se de uma forma política bastante flexível em oposição aos modelos repressivos cujo centro é o Estado e seu conjunto de tentáculos opressores - polícia, magistratura, exército, burocracia (MARX, 2016, p. 59). Desse modo, "com o trabalho emancipado, todo homem se converte em trabalhador e o trabalho produtivo deixa de ser um atributo de classe" (MARX, 2016, p. 59). Eis o segredo da Comuna, para Marx: “era essencialmente um governo da classe operária” (MARX, 2016, p. 59).

A Comuna é "a forma política da emancipação social, da libertação do trabalho da usurpação dos monopolistas dos meios de trabalho, sejam estes meios criados pelos próprios trabalhadores ou dados pela natureza" (MARX, 2016, p. 131). A Comuna, entretanto, de acordo com a análise de Marx, não foi o fim a que se chegou pela luta de classes, o cume da linha da história. Para ele, ela não elimina a luta de classes. Com efeito, ela não representa um interesse particular, mas a libertação do "trabalho" (Marx usa o termo entre aspas). Libertação do "trabalho", ou seja, "a condição fundamental e natural da vida individual e social que apenas mediante usurpação, fraude [...] pode ser exercida por poucos sobre a maioria" (MARX, 2016, p. 131). A Comuna "fornece o meio racional em que essa luta de classes pode percorrer suas diferentes fases da maneira mais racional e humana possível" (MARX, 2016, p. 131). Ela inaugura a emancipação do trabalho, segundo Marx seu grande objetivo (MARX, 2016, p. 131). E o faz, de um lado, ao remover a obra danosa dos parasitas estatais, pois deixa de enviar a estes uma quantidade de dinheiro que sacrifica a produção nacional. De outro, realiza o trabalho de administração por salários de operários (MARX, 2016, p. 131). Desse modo, afirma, "ela dá início [...] a uma imensa economia, a uma reforma econômica, assim como a uma transformação política" (MARX, 2016, p. 131).

Como atesta a história, o modelo implantado em Paris pela Comuna foi destruído pelo exército mercenário de Bismark no acordo espúrio feito entre este e os donos do poder na França. Escreve Marx: "A conspiração da classe dominante para esmagar a revolução por meio de uma guerra civil realizada sob o patrocínio do invasor estrangeiro [...] culminou na carnificina de Paris" (MARX, 2016, p. 76-77).

Ponto mais alto de uma ilusão? Ou fonte calada por interpretações históricas interessadas no aniquilamento da verdadeira memória desta rica experiência institucional de igualdade? Questão aberta. A Comuna seria, segundo Marx, a experiência genuína de tomada de poder pelos operários, a qual foi massacrada pelas forças do status quo, e não a experiência da ex-URSS e seus desmandos e desvios em face do verdadeiro projeto de distribuição de poder. Um capitalismo de Estado teria 
sido a experiência da ex-URSS? Questão igualmente aberta.

Contraponto à possibilidade de efetivação - em escala - da práxis da Comuna de Paris remonta aos primórdios da invenção da filosofia política moderna, que pode qualificar o debate, à medida que se tome em conta que os desejos e os apetites humanos são insaciáveis (MAQUIAVEL, 2007, p. 180). Dado tal pressuposto, como instituir o comum, a Comuna, sob a força de desejos e de apetites, a promoverem o entredevorar-se dos homens, em meio às ambições desmedidas? As institucionalidades políticas contemporâneas conseguiriam controlar a força insaciável dos instintos, próprios da natureza humana? Por certo a constatação tem propriedade suficiente para apresentar-se rediviva no presente. Mesmo que o contrato social ou a constituição tendam a equacionar o dado básico da natureza e da condição humanas, de par com controles sociais tidos por eficientes e, no mesmo passo, a largueza aos vieses licenciosos.

Por certo, apenas a História, mestra dos homens e ciência que abarca todas as outras, poderá facilitar a compreensão de tais problemas. Aos moldes do modelo platônico presente em muitos dos Diálogos, estas reflexões terminam em aporia. A ênfase na pergunta, entretanto, do ponto de vista da filosofia política, poderá redundar em mais potência, prudência e virtù da população votada à práxis transformadora que as possíveis respostas. - Afinal, como construir a cidadania autogestionária, sem perder de vista o homem como animal capaz de prometer? Machado de Assis enfeixa o romance Iaiá Garcia com o rasgo de sabedoria: "Alguma coisa escapa ao naufrágio das ilusões" (MACHADO de ASSIS, 2015, p. 595). Sem remordimento, Chico Buarque desencanta: "Do outro lado do seu espelho / Desfigurado / Ilusão / Ilusão / Veja as coisas como elas são" (CHICO BUARQUE, 1984).

\section{REFERÊNCIAS}

ANDRADE, C. DRUMMOND de. "Epigrama para Emílio Moura", In ANDRADE, C. DRUMMOND de., "Alguma Poesia", In ANDRADE, C. DRUMMOND de Poesia e Prosa, Rio de Janeiro, Nova Aguilar, 1979, pp. 93.

BENJAMIN, W., Documentos de Cultura. Documentos de Barbárie (Escritos Escolhidos), tradução Celeste H. M. Ribeiro de Sousa, Willi Bolle et alii, São Paulo, Cultrix / Edusp, 1986.

BOBBIO, N., A Era dos Direitos, tradução Carlos Nelson Coutinho, Rio de Janeiro, Elsevier, 2004.

BOVE, L., Vivre contre un mur: diagnostic sur l'état de notre nature en regime de terreur ordinaire, Multitudes, 2/2008 $\left(\mathrm{n}^{\mathrm{o}}\right.$ 33), pp. 111-122. Disponível no link http://www.cairn.info/revue-multitudes-2008-2-page-111.htm. Acesso: 06 JUN 2011.

BOVE, L. Espinosa e a psicologia social: ensaios de ontologia política e antropogênese, Belo Horizonte, Autêntica, 2010, pp. 89-98. (Coleção Invenções Democráticas).

CAMÕES, Luís de, Os Lusíadas, Porto, Editora Porto, 1974.

CHICO BUARQUE, canção "As cartas", álbum Chico Buarque, 73145100032, faixa 9, Universal Music, 1984.

COMPARATO, Fábio Konder, A afirmação histórica dos direitos humanos, São Paulo, Saraiva, 2001.

Declaração de Direitos do Bom Povo da Virginia - 1776. Disponível no link

http://www.direitoshumanos.usp.br/index.php/Documentos-anteriores-\%C3\%A0cria\%C3\%A7\%C3\%A3o-da-Sociedade-das-Na\%C3\%A7\%C3\%B5es-at\%C3\%A9-

1919/declaracao-de-direitos-do-bom-povo-de-virginia-1776.html, acessado dia 05 de junho de 2020.

Declaração de Direitos do Homem e do Cidadão - 1789. Disponível no link 
http://www.direitoshumanos.usp.br/index.php/Documentos-anteriores-\%C3\%A0cria\%C3\%A7\%C3\%A3o-da-Sociedade-das-Na\%C3\%A7\%C3\%B5es-at\%C3\%A9-

1919/declaracao-de-direitos-do-homem-e-do-cidadao-1789.html, acessado dia 05 de junho de 2020.

Declaração Universal dos Direitos Humanos - 1948. Disponível pelo link https://nacoesunidas.org/wp-content/uploads/2018/10/DUDH.pdf, acessado dia 05 de junho de 2020.

ELIOT, T. S., Poemas 1910-1930, tradução Idelma Ribeiro de Faria, São Paulo, Hucitec, 1980.

LISSAGARAY, P.-O., História da Comuna de 1871, tradução Sieni Maria Campos, São Paulo, Ensaio, 1991.

MACHADO de ASSIS, J. M., "Iaiá Garcia”. Obra Completa, volume I, São Paulo, Nova Aguilar, 2015, pp. 490-595.

MARITAIN, J., Cristianismo e democracia, tradução e introdução de Alceu Amoroso Lima, Rio de Janeiro, Agir, 1964.

MAQUIAVEL, N., O Príncipe, tradução, introdução e notas de Diogo Pires Aurélio, São Paulo, Editora 34, 2017. (Edição bilíngue).

MAQUIAVEL, N., Discursos sobre a primeira década de Tito Livio, São Paulo: Martins Fontes, 2007.

MARX, K., "A Chamada Acumulação Primitiva". O Capital: Crítica da Economia Política, Livro I, O Processo de Produção do Capital, Cap. XXIV, tradução Rubens Enderle, São Paulo, Boitempo, 2013, pp. 785-833.

MARX, K., Sobre a questão judaica, tradução Nélio Schneider; Wanda Caldeira Brant, São Paulo, Boitempo, 2010.

MARX, K., A guerra civil na França, tradução Rubens Enderle, São Paulo, Boitempo, 2016.

MONTAIGNE, M. de, Ensaios, tradução Sérgio Milliet, São Paulo, Abril Cultural, 1980. (Coleção Os Pensadores).

MUSETTI, F. R., Da República Social à ditadura bonapartista: a crítica da política em $\mathrm{O} 18$ de Brumário de Luís Bonaparte, dissertação de Mestrado em Filosofia, PUC-SP, dez. de 2014. Acessível pelo link https://tede2.pucsp.br/handle/handle/11670, acessado dia 13 de junho de 2020.

NIETZSCHE, F., Genealogia da Moral. Uma polêmica, tradução Paulo César de Souza, São Paulo, Cia. das Letras, 1998.

PICO della MIRANDOLA (Giovanni Pico, conde de Mirandola e de Concórdia), A Dignidade do Homem, tradução Luiz Ferracine. Campo Grande: Solivros/Uniderp, 1999.

PUFENDORF, S., Os Deveres do Homem e do Cidadão de acordo com as Leis do Direito Natural, tradução Eduardo Francisco Alves, Rio de Janeiro, Topbooks, 2007.

RAGO FILHO, Antonio, "Apresentação", In MARX, K., Guerra civil na França, tradução Rubens Enderle, São Paulo, Boitempo, 2016, pp. 09-20.

SCHWARZ, Roberto, Corações Veteranos, Rio de Janeiro, Civilização Brasileira, 1974. (Coleção Frenesi).

SESSHU/ MARSICANO, A., Sendas Solares, São Paulo, Massao Ohno-Roswitha Kempf, 1980.

STEINER, G., No Castelo do Barba Azul: algumas notas para a redefinição de cultura, tradução Tomás Rosa Bueno, São Paulo, Cia. das Letras, 1991.

\section{Filmografia}

Apocalypse Now, direção de Francis Ford Coppola, USA, United Artists, 1979. 1 DVD (153 min).

\section{Dramaturgia}

Hair, direção: Milos Forman, USA, MGM, 1999. 1 DVD (121 min).

\section{Notas}

1 ELIOT, T. S., “The Hollow Men”, In ELIOT, T. S, Poemas 1910-1930, tradução Idelma Ribeiro 
de Faria, São Paulo, Hucitec, 1980, p. 62. - "Os Homens Ocos”. "Nós somos os homens ocos / Os homens estofados/ Uns nos outros apoiados / O crânio cheio de palha. Ai! / Em mútuos cochichos / Nossas vozes secas / Frouxas sem sentido / São vento em capim seco / Pés de rato pisando / Vidro partido / Em nossa adega seca / Figura sem forma, sombra sem cor,/ Força entorpecida, gesto sem expressão; (ELIOT, 1980, p. 63)."

842 Sobre o tema do fascismo ordinário, ver ensaio de Laurent Bove, em interpretação a partir de Espinosa, no qual propõe um diagnóstico sobre o terror ordinário presente no mundo contemporâneo: BOVE, L. Vivre contre un mur: diagnostic sur l'état de notre nature en regime de terreur ordinaire. Multitudes, 2/2008, $\mathrm{n}^{\circ}$ 33, pp. 111-122. Disponível em: http://www.cairn.info/revue-multitudes-2008-2-page-111.htm. Acesso: 06 JUN 2020. Afirma o autor: "O terror não é apenas um simples sentimento de medo, e mesmo de pânico extremo, mas o poder mortal, silencioso e secreto que distancia o coração e o espírito da identificação espontânea à dor do semelhante.” (p. 118) (tradução livre). Artigo traduzido em: BOVE, L., Espinosa e a psicologia social: ensaios de ontologia política e antropogênese. Tradução de Moara Passoni e Maurício Ayer. Belo Horizonte: Autêntica, 2010, pp. 89-98. (Coleção Invenções Democráticas)

3 Também em 1486, do outro lado do mundo, na China ou no Japão, o poeta zen Sesshu concluía a obra Sendas Solares. A par da coincidência das datas, o poeta afirmava ter aprendido, não com os homens, mas com os rios e as montanhas. Conferir SESSHU/ MARSICANO, A., Sendas Solares, São Paulo, Massao Ohno-Roswitha Kempf, 1980.

4 Eis o verso de Lucílio: "ita ut quisque nostrum e bulga est matris in lucem editus" (assim a cada um de nós é dado à luz do ventre da mãe).

5 A citação reproduz tal qual a tradução, com letras maiúsculas para substantivos e outras palavras, conforme o original, em sueco.

6 Ver também SILVA, Jailane Pereira da, Walter Benjamin e o Direito: violência pura como estado de exceção, Rio de Janeiro, Lumen Juris, 2018.

7 Idem. Nota de rodapé 1, do Tradutor, p. 160.

$8 \mathrm{O}$ Autor analisa, histórica e hermeneuticamente, vários documentos históricos, que expressariam a tese da afirmação histórica dos direitos humanos.

9 Disponível no link: http://www.jornaldepoesia.jor.br/tmello.html\#estat. Acessado em 20 de Julho de 2020.

10 Os dois textos de Bauer, em tradução francesa o primeiro, e em tradução ao espanhol o segundo, estão disponíveis nos links: https://boitempoeditorial.files.wordpress.com/2010/06/bruno-bauer.pdf. https://blogdaboitempo.com.br/2010/11/11/segundo-texto-de-bruno-bauer-criticado-pormarx-em-sobre-a-questao-judaica/. Acessados dia 20 de Julho de 2020.

11 O termo "marxista" e seu uso, em geral, arrasta consigo uma conotação pejorativa acerca do pensamento filosófico-político de Marx, em contraste ao termo "marxiano", que o insere na linguagem filosófica sem conotações.

12 Durou 72 dias. - Há quem lamente o fato de Marx e Bakunin não estarem presentes em Paris ao tempo dramático da Comuna. Conferir RAGO FILHO, Antonio, "Apresentação", In MARX, K., Guerra civil na França, tradução Rubens Enderle, São Paulo, Boitempo, 2016, pp. 09-20.

13 O Tradutor de O Príncipe, de Maquiavel, Diogo Pires Aurélio afirma à nota 37: "Giorgio Inglese anota que o cronista Piero Valenti põe na boca de Giorgio Scali, citado no final do parágrafo, uma versão bem mais crua do provérbio. Assim: "quem se funda no lodo, com vossa licença, funda-se na merda (MAQUIAVEL, 2017, p. 151).” A propósito da multidão na política, ver MAQUIAVEL, Discorsi, I, 58, cujo título é "A multidão é mais sábia e constante que um príncipe."

14 A propósito do bonapartismo, ver MUSETTI, F. R., "Cap, III - 'Da República ao Bonapartismo: o Segundo Dezoito de Brumário na Gênese do Estado", dissertação de Mestrado em Filosofia, PUC-SP, 2014. 